\title{
FOOTBALL, BRAZIL AND THE ROLE OF THE PUBLIC INTELLECTUAL
}

\author{
FUTEBOL, BRASIL E O PAPEL DO INTELECTUAL PÚBLICO \\ FÚTBOL, BRASIL Y EL PAPEL DE LO INTELECTUAL PÚBLICO
}

Grant Jarvie*

Keywords

Football.

World Cup.

University.

Social Protest.

Intellectual.
Abstract: The concerns in this essay relate to questions about the role of the public intellectual and the university as a resource to address public issues and actively embrace public engagement as part of the university contract. The essay draws upon the social and political protests in the build up to the 2014 FIFA World Cup in Brazil as a basis for researching two questions: What are universities for? What opportunities are provided though sport to act as a public intellectual and a resource of hope in the world today? This small study of football, Brazil and the role of the intellectual draws upon both secondary and primary sources. The article concludes by recommending that those working in and through sport in the university have an ideal medium to work with the public on issues that matter to the public, and should use this opportunity to the full.

Resumo: Este ensaio trata de questões relacionadas a questionamentos sobre o papel do intelectual público e da universidade como recursos para tratar de questões públicas e assumir ativamente 0 engajamento público como parte do contrato universitário. 0 ensaio trabalha com os protestos sociais e políticos que antecederam à Copa do Mundo da FIFA, em 2014, no Brasil, como base para pesquisar duas interrogações: Para que servem as universidades? Que oportunidades são proporcionadas pelo esporte para se atuar como intelectual público e ser recurso de esperança no mundo de hoje? Este pequeno estudo sobre o futebol, o Brasil e o papel do intelectual se baseia em fontes primárias e secundárias. $O$ artigo conclui com a recomendação de que as pessoas que trabalham no esporte e por meio dele na universidade têm um meio ideal para trabalhar com o público sobre as questões que são importantes para o público, e devem usar integralmente essa oportunidade.

Resumen: Las preocupaciones de este ensayo están relacionadas a cuestionamientos sobre el papel del intelectual público y de la universidad como recurso para tratar de cuestiones públicas y asumir activamente el compromiso público como parte del contrato universitario. El ensayo trabaja con las protestas sociales y políticas que antecedieron a la Copa del Mundo de la FIFA, en 2014, en Brasil, como base para investigar dos cuestiones: ¿Para qué sirven las universidades? ¿Cuáles son las oportunidades proporcionadas por el deporte para actuar como intelectual público y ser recurso de esperanza en el mundo de hoy? Este pequeño estudio sobre fútbol, Brasil y el papel del intelectual está basado en fuentes primarias y secundarias. El artículo concluye con la recomendación de que las personas que trabajan en el deporte y a través de él en la universidad tienen una herramienta ideal para trabajar con el público sobre las cuestiones que son importantes para el público, y deben usar integralmente esa oportunidad.
* Chair of Sport. Sport, Physical Education and Health Sciences (SPEHS), Moray House School of Education, The University of Edinburgh, Edinburgh, Eh8 $8 \mathrm{AQ}$, Scotland, United Kingdom. Email: grant.jarvie@ed.ac.uk

Recebido em: 26-05-2014 Aprovado em: 18-10-2014 (c) (1) (8) Licence 


\section{INTRODUCTION}

Addressing an audience of university academics in 2012, Michael Burawoy asked if the universities in our society were ready to join the crowd. As an advocate and voice for a more public sociology, he was championing the need for sociologists, amongst others, to take a genuine interest in pursuing relationships with publics beyond the university. Here was a plea that the university can no longer be seen apart from society but must in fact be embedded in society. The question is much broader than sociology, although sociologists have the opportunity to be more visible and lead in the societies and communities of which they are a part. Individuals cannot do it themselves, and therefore Burawoy's call is in fact a call to those working in universities to embark on a collective project; to seek and work with broader publics because, in Burawoy's (2012, p. 29) own words, "our livelihood is at stake".

It is a turbulent and challenging time, and not just for universities but also the societies and communities in which they are located. Football, as an institution, is also faced with challenges of corruption, bribery and insider dealing (see JENNINGS, 2006 and numerous examples of FIFA corruption exposed on the playthegame.org website). At the time of writing, FIFA is facing the consequences of an evidence trail leaked to and exposed by the British newspaper, The Sunday Times, evidencing the fact that more than US\$5 million was paid to senior football officials to generate support for Qatar's 2022 World Cup bid (CALVERT; BLAKE, 2014, p. 1). The Sunday Times revealed the secret payments that helped Qatar to win the bid. It is doubtful that any event in sports since the 1972 "Munich massacre" has captured so much media attention in the United Kingdom (UK).

It is the inter-section between these two very public institutions, universities and football that is the focus of this study. It champions university intellectuals who were part of the social base supporting the $20^{\text {th }}$ FIFA World Cup in Brazil, while also acknowledging the role of public intellectuals in the social and political protests that surrounded the build up to the World Cup.

\section{THE CONFEDERATIONS CUP, BRAZIL AND A PUBLIC INTELLECTUAL}

Brazil's 3-0 victory over 2010 FIFA World Champions, Spain, in the final of the 2013 Confederations Cup may have provided Brazil's President Rousseff and her government with some short-term positive psychic income. However, the protesters outside the Maracana Stadium, before the game started, were a reminder that Brazil was experiencing its biggest protests since 1992. Similarly the $19^{\text {th }}$ June, 2013 , was scheduled to be a celebration in Fortaleza. As Brazil prepared to take on Mexico in the Confederations Cup Match, Fortaleza was being celebrated as the first city in Brazil to complete construction of its 2014 World Cup Stadium. The expected newspaper headlines were those of the Brazilian victory (RODRIGUES; BRANCOLI, 2014). Instead, voices from within many of the Brazilian favelas were asking who the 2014 FIFA World Cup was for? According to the United Nations, Fortaleza is ranked fifth in the world in terms of inequality; yet preparations for the World Cup allegedly included the removal of 5,000 of Fortaleza's poor to the periphery of the city. The renovation of the Fortaleza stadium cost $£ 149$ million (BURT, 2013, p. 6).

Several days into the wave of protests that gripped Brazil in mid-2013, a lecturer from the Federal University of Rio de Janeiro argued that, "whether it be about football or bus fares 
the scale of last week's protests has been extraordinary - more than 200,000 people took to the streets of the country" (MELO, 2013, p. 2). This passionate public intellectual pointed out the social and political complexity of the June, 2013, protests when he went on to explain how dozens of native Brazilian indigenas had occupied an empty derelict building next to the Maracana Stadium since 2006. More specifically:

The government intended to build a parking lot next to the stadium in order to provide infrastructure for the World Cup, and the occupiers were evicted after the police used pepper spray, tear gas, electric shock and rubber bullets against them. Protesters, who tried to demonstrate peacefully, were also suppressed, as were some reporters. Some state legislators were amongst the protesters trying to mediate the eviction (MELO, 2013, p. 2).

To be fair, the social and political protests that gripped Brazil in the year before the 2014 FIFA World Cup are reminiscent of other voices of protest, including those of intellectuals, which have been heard before other major sporting events in other countries. In October 2009, several months before South Africa's FIFA 2010 World Cup started, there was a violent demonstration in a black township adjacent to Soccer City Stadium in Johannesburg. The stadium had been refurbished and extended at an estimated cost of $£ 308$ million. The residents of the township of Riverlea, questioned why "the government is pouring money into the World Cup? Why are they not pouring money into housing?" (BOND, 2009, p. 17).

Similarly, before the 2010 Vancouver Winter Olympic Games there were protests over land use, housing, civil liberties, the environment, and use of taxpayers' money (BOYKOFF, 2011). It would be wrong to conclude that civic and popular activism around major sporting events is simply about sport, since a broad range of demands are usually made and these extend well beyond the event or the tournament itself. The protests in Brazil reflect growing frustration and resentment over issues such as national education levels, the quality of public services, high levels of poverty and unemployment, rising food costs, limited availability of affordable housing, and concerns about corruption in high office. For many people the popular reality of life in Brazil contrasts bleakly with the optimism espoused by political leaders and authorities.

Yet the June 2013 protests in Brazil acquired such magnitude and energy that it has become clear that something was happening deep inside Brazilian society. Though the initial protests were mainly concentrated in Porto Alegre and Sao Paulo, the protest movement expanded to more than 350 cities and towns bringing millions of people into the streets. The scale and velocity of the protests forced authorities to cancel a planned increase in transport fares, and posed a real threat at the time to the Confederations Cup and the preparations for the 2014 FIFA World Cup.

These concerns from Brazil should not be seen in isolation from the broader context of global protests in, for example, Spain (Madrid- Puerta Del Sol); Egypt (Cairo-Tahrir Square); Turkey (Istanbul-Taksim Square) and the USA (New York- Zuccotti Park). All of these witnessed young, educated, in some cases well off citizens protesting against governments of the day.

That sport has not always figured in such events adds weight to the argument that protests involving sport may at times be about time, place and context, and should not detract from the more positive influence that sport may have. As the time of writing, just prior to the 2014 FIFA World Cup, it is difficult to forecast what the event will be remembered for (see postscript/ Section 5). 
Events such as those in Fortaleza, Vancouver and Johannesburg illustrate that sport is not immune from underlying political currents. The high visibility, relatively high cost, and popularity of sporting events make them potential popular platforms and targets for protesters who want to convey social and political messages. The young lecturer from the Federal University of Rio de Janeiro was unequivocal in claiming that the message from Brazil seemed to be that world sporting events are overwhelmingly benefitting some people while there is little real material benefit for the majority. Events such as the World Cup, and the Olympic Games in Brazil, run the danger of becoming vehicles for carrying the message that the current authorities are failing to narrow the gap between rich and poor.

The questions posed so urgently in June 2013 remain unresolved and the discontent still simmers. The tectonic plates of Brazilian society appear to be shifting and, while others such as Singer (2014) have attempted to sketch the social make up and education levels of the protesters, the contribution that I wish to make in this edition of Movimento concerns sport and the public intellectual and, in particular, the part that can and perhaps should be played by those working in universities. As the lecturer from the Federal University of Rio de Janeiro concluded, "while the protesters have won the bus fares battle the struggle for Brazil's future goes on" (MELO, 2013, p. 3).

\section{UNIVERSITIES, PUBLICS AND THE ORDINARY}

The actions of the Brazilian lecturer in supporting and reporting the popular public protests serve to remind us not just of the role of the committed public intellectual but also that the place of the university, leading in the societies of which they are a part, is needed more than ever. The popularity and visibility of sport on the world stage mean that opportunities surrounding major sporting events are always going to present themselves to social and political activists, including those in and from sport who see sport as helping to secure resources of hope in what are challenging times. Those working through sport in universities can make timely interventions in support of a more vibrant, democratic and aspirant public realm, a fact that has been recognized in some of the critical sociological literature about universities and their role in the $21^{\text {st }}$ Century (ADONIS, 2012; COLLINI, 2012; DOCHERTY, 2011; GONZALEZ, 2011; GOURLEY, 2002; HIND, 2012; JARVIE, 2013; KERR, 2009, 2001; REID, 1972; SUTHERLAND, 2011; SKULASON, 2010; WILLIAMS, 1989).

Universities, those working in them, and intellectuals come in many different guises. The university itself is a community of researchers, teachers, students and administrators whose steady purpose has been described by one President as "the acquisition, preservation, discovery and transmission of knowledge in the service of humanity"1

A Principal of one Scottish university talked of university priorities as being:

Providers of trained personnel, creators of useful knowledge, attractors of research investment and talented individuals, as nuclei for creative economic clusters, engaging public bodies but also a body of autonomous academics who play the role of public intellectuals as stimulators of social action and facilitators of social mobility, social justice and cultural engagement. ${ }^{2}$

1 Interview by the author, 12 March, Provost, University of Helsinki, Edinburgh, 2012.

2 Interview by the author, 7 February, Principal, University of Glasgow, Glasgow, 2014. 
As publicly assisted institutions, universities in some countries have stood the test of time, and while other public institutions such as banks or football clubs may in some cases be remodelled, or even disappear, universities are enduring institutions which, according to one Provost, "through the centuries have focused upon the basic fact of human existence"

More than 40 years ago the rector of the University of Glasgow, in an address to students, employees, the unemployed, academics and the assembled public titled Alienation, not only called for the creative use of leisure but sent a searing message to those in positions of power and influence to help others (REID, 1972, p. 5). He talked of the "cry of the people" who feel themselves to be victims of blind economic forces beyond their control. On the question of unemployment Reid (1972, p. 15) was unequivocal: "any society which permits over one million people to be unemployed is far too permissive". He called for those working in universities to take their place in the vanguard of a movement for the bettering of humanity by taking a stance, providing leadership in society, and speaking truth to power (REID, 1972).

It might be interesting to ask if Reid's Alienation speech simply concerned one university, one assembled public, and one country; or would this speech delivered in the early 1970s resonate with the $21^{\text {st }}$ century or with the people demonstrating in Brazil in June, 2013. Both serve as a reminder that there is no single agent, group, university or organization that can carry the hopes of humanity, but that there are many points of engagement through universities, public intellectuals and through sport that offer resources of hope and causes for optimism that things can get better. That being said universities need to be seen to be leading in the societies and communities that they are a part of, and those working in them need to be publicly engaged, supporting public causes and aspiring to help to create an aspirational public realm for all.

One of the ideal venues for debate and action about sport is certainly the university campus; but perhaps it is more important for those debates and actions to extend to spaces and places beyond the university campus. If universities in the 21 st century do not provide their students and staff with the forums and tools to at least discuss and discover what their responsibilities are to their fellow human beings, and help students and staff to develop the requisite normative compass to navigate the treacherous path of increasing or decreasing interdependence, then they could be failing in their mission. Universities should be key sites for asking about, if not solving the problems of our time. Sport can connect with many of the key questions of our time, but it can also challenge the idea of the university to be more than just an ideal or idea in and of itself, to live up to the promise of being a university and to emphasize the necessity for it and its members to revive politics in relation to the question of the university and its place in the world we live in.

Much more could be done if researchers, students, and teachers of sport regarded themselves less as academics and more as a public resource to help or intervene in some or all of the many worlds of sport. The notion of the public intellectual may not be perfect, but it is a useful place to start. The role of the public intellectual in sport is fundamentally different from the role of the academic in sport, but they can both work on behalf of the public, for the public, and with the public on public issues. Public intellectuals are not only different from academics, but almost the opposite of them. Academics usually, but not always, plough a narrow disciplinary or a conservative inter-disciplinary path, whereas public intellectuals roam ambitiously from one area to another (HIND, 2012). Academics are interested in ideas, research and analysis where-

$\overline{3 \text { Interview by the author, }} 10$ November, Former President, University of St Andrews, Toronto, 2013. 
as public intellectuals are more concerned with the intersection between research, analysis and public debate, ideas and helping ordinary people. The decisions about sport, and the part of the social contract that involves matters of sport, can only work if we have honest argument, real information and public engagement. Researchers need to ask critical questions, not only about what is going on in the world, how we make sense of what is going on in the world, and what evidence we have, but also, what we are going to do about issue $x$ or $y$.

The critical literature on sport and public intellectuals is both contemporary and varied. It is worth remembering Raymond Williams' (1989) influential essay, Culture is Ordinary; and it is perhaps worth suggesting that intellectuals are ordinary in the sense that they are indeed part of the cultural landscape of all complex societies. Ordinary in the sense that it is neither unthinkable nor shocking to apply the noun intellectual to some of one's friends, or colleagues, or social and political activists who may or may not work in universities. That is to say, stereotypes or labels can sometimes become barriers when the challenge at hand requires committed and aligned groups of people, some of whom may work in universities but all of whom may be committed to change, providing alternatives, attempting to alter life chances, and striving to narrow the gap between rich and poor.

\section{SPORT AND PUBLIC, ORGANIC AND VERNACULAR INTELLECTUALS}

With the above in mind it is worth continuing to think about not just the idea of what universities are for and what those working in them can do, but also about sport, universities and public intellectuals helping to bring about what Williams called "the art of the possible" (WILLIAMS, 1989, p. 34). In writing his book Resources of Hope (1989), Williams championed the need for commitment. He also argued that artists, writers, and academics had to balance their freedoms with a duty to strive to help others in the art of the possible. Sport can make the art of the possible, possible, in so many ways, and we should exploit it to the full. But such a goal would be enhanced if those working in both universities and sport help to lead in the societies and communities to which they belong - practicing the art of the possible with universities and sport working for the public, on behalf of the public, and with the public on matters that are of concern to the public. Making the art of the possible, possible involves making sports policy, sports investment, sports research, and sports advocacy; and it involves commitment, alignment, and engaging the power of universities to work for people, places and communities.

Such an art is only strengthened if we acknowledge some of the criticisms of the way in which universities operate in the $21^{\text {st }}$ century. Critics such as Docherty (2011) have championed and questioned the first principles of the university as they operate to-day. The principles explored by this author in relation to the future of any university apply equally to the promise and possibility of sport in and through universities, with both sport and the university, and those working in sport in the university, helping to forge and contribute to social justice and social causes.

Docherty's (2011) principles are not exhaustive. Sport is about search because the university is, in part, governed by actions of discovery and inventiveness and the possibilities that are opened up through the on-going adventure of discovery. Individuals working in universities in the area of sport do research, are involved in discovery, and add value in a number of ways. An openness to possibility requires a spirit of freedom, and the idea of a university exists for the extension of freedom and/as development. This in turn allows those working in and for sport to attend 
to questions of judgment, and judgment in turn allows those working in universities and others to search for the idea of justice, or what constitutes justice. If justice is to be shaped or shared by a community then it will depend upon a certain kind of democracy. Whether it is through research and/or public engagement, the promise and possibilities of sport, and the idea of a university, are both helped by these first principles of search, discovery, freedom, justice and alignment.

Within this context of the idea of a university one can add or revisit the notion of public intellectualism, concerns over the decline of the public realm, and worries about any void in democracy (BAIRNER, 2009; JARVIE, 2007; JARVIE; THORNTON, 2012). Public intellectualism may be considered at many different levels, such as writing for the public about an area in which one has a particular knowledge, speaking about and writing about one's own area of study and how it connects with the social, political and economic world, or by invitation, where one is provided with a platform to talk to an issue or represent a body of knowledge, but also to speak on public issues of the day. Many other possibilities clearly exist. Most intellectuals manage to perform the social role assigned to them by Gramsci in either a traditional or an organic sense, but only an increasingly tiny minority manage to speak truth to power, or set themselves apart in order to become dispassionate and effective, ask embarrassing questions, confront orthodoxy and dogma, and resist being co-opted easily by governments, institutions, or corporations.

Public intellectuals have been defined here as those who are able to work on behalf of the public, on public issues, and who use the opportunities open to them to speak truth to power. The use of the term "public intellectual" in relation to sport has been challenged by writers such as Bairner (2009), who are dismissive of the term in preference for the notion of "organic intellectuals" in the Gramscian sense. The author of this article has also commented upon the difference between public and organic intellectuals (JARVIE, 2013), but Bairner's reflections are worth recalling.

Bairner (2009) asserts that much of decline in public intellectualism is related to the changing nature of the environment in which academics now work, and that public intellectualism should not be confused with social activism. Bairner draws a narrow distinction between public intellectuals, in the widest sense of the term, and social activists working in the field of university sport. The lack of public engagement with sport, according to Bairner (2009, p. 117), might: (i) be due to the constraints of academic life; (ii) be a result of the fact that sociologists of sport, amongst others, may have become too close to sport or to government; (iii) be because public intellectuals, as opposed to organic intellectuals, are limited in terms of what they are able to achieve in the world of sport (BAIRNER, 2009, p. 127); and (iv) confirm that what is required is organic intellectuals helping public sociology to convey important messages to multiple publics. Bairner offers some helpful guidance in relation to academics being accepted or rejected by the world of sport itself, but in all of the above the degree of power one has or is able harness is as much a question of strategy as reality, and need not result in the scenario described by Bairner.

Despite Bairner's (2009) observations about tactical entry points into the debate about sport, there is undoubtedly considerable cynicism about the demise of national mainstream politics, and for the prospects of a more just and less charitable social order in which important social and political problems are not reduced to matters of efficiency or profit. This is as true for Brazil today as it is for many other places and communities. Writers such as Sontag (2002), Said $(2001)$ and Sen $(2009,2006,2001,2000)$ remind us of the impressive array of opportunities offered by the lecture platform, the pamphlet, the radio, the interview, the internet, the research newsletter, the guest lecture, and the letter to the newspaper. These are all open to a 
wide variety of public intellectuals. Speaking about the role of the public intellectual in the USA, Gilroy (2011) recognised that new technologies impact upon the idea of public intellectualism directly, because new technologies provide a very different kind of platform.

Questioning the capacity of sport to assist with social change is perhaps an option for public or organic intellectuals interested in understanding what sport can do. But perhaps doing nothing is no longer an option for the socially concerned or responsible university worker, athlete, university president or club owner - all of whom need to show alignment and commitment if the art of the possible is to become possible.

Durkheim once insisted that professional associations should always be an integral part of national political life - and not just function to defend their own narrow professional interests. A public intellectual involved in sport would not simply be an intellectual who does work in public, but one who does intellectual work in public on public issues and concerns involving sport. One of the most important roles of the public intellectual in sport involves having the capacity to see above and beyond existing debates, to avoid status quo discussions - perhaps to challenge that status quo - but certainly to provide a level of independence that think-tanks often cannot provide because of the constraints of funding. Bairner, might acknowledge that Edward Said (2001, p. 16) was explicit about the role of the intellectual which was to "uncover the contest, to challenge and defeat both an imposed silence and the normalised quiet of unseen power" wherever and whenever possible. Said presented a powerful case for regarding intellectuals as those who are never more themselves than when moved by passions and the principles of justice and truth; when they are denouncing corruption, defending the weak, and defying imperfect or oppressive authority. Indeed there is a common overlap here with Docherty's (2011) guiding principles.

Finally, there is the case of the vernacular intellectual, who addresses and confronts social injustice and may not be organised through or connected to organised political structures. In a study of vernacular intellectuals, Farred (2003) developed a category of the involved thinker as a vernacular intellectual. It is perhaps worth pointing out that the purpose of this is not to confuse or add complexity to a debate about intellectuals. Rather, it is about the individuals working in university settings, individuals who have a range of platforms and opportunities to influence and move forward public debate about a wide range of concerns arising out of an interest in and commitment to sport and public life.

Areas and issues of concern change with the context and time-period, but the problems and issues confronted by the Brazilian public intellectual in Rio de Janeiro would also be familiar areas of concern for organic, traditional, vernacular and/or all public intellectuals. Extending Gramsci's notion of the organic intellectual, Farred conceives of vernacular intellectuals as individuals who address and confront social injustice from both inside and outside traditional academic or political spheres. According to Farred (2003, p. 22), the vernacular intellectual, unlike the traditional or organic intellectual is in no way connected to organised political structures. These figures emerge out of the vernacular experience, they craft a public space, and they address issues of the day that directly affect the communities in which they operate.

Celebrity status, writes Cooper (2008), often empowers athletes to pronounce on a range of subjects in the civic domain. Such celebrities tend to be ideologically mobile, and can often talk for or certainly connect with a range of subjects often excluded from public platforms and formal public debates. Didier Drogba used his celebrity as a footballer, and the Ivory Coast's qualification for the 2006 World Cup in Germany, to try to ease tensions in his country: 
"The only country in Africa with such wealth cannot sink into war like this! Please, put down your weapons, organize the elections and things will get better". The intervention became known as Drogba Diplomacy.

Sandra Mizra was once ranked as potentially one of the most powerful people in the world because of the symbolism attached to her tennis and beliefs. In a 2000 list of the top 10 people likely to have an impact on the world, she ranked tenth behind a then unelected Barak Obama (who ranked first). The first female Indian tennis player to achieve a top 40 ranking in world tennis, she had the potential to be a role model for an entire generation of Muslim girls in a country where women have typically been discouraged from taking part in sport. At Wimbledon she wore a T-shirt bearing the slogan "well behaved women barely make history", and at the US Open, where she lost in the quarterfinals to Maria Sharapova, she wore another T-shirt that read "You can either agree with me or be wrong". She was attacked by some Muslim clerics who clearly recognised the impact of sport in changing attitudes, and the power of a young, attractive, media smart teenage Muslim tennis star to shake traditional hierarchies.

The difference between vernacular and organic intellectuals is that the former are grounded in often-disenfranchised communities and, for Farred (2003, p. 12), it is this situation or location that is one of the differences. Vernacular intellectuals, in this sense, are grounded in sport or are from sport, and they understand the challenges and language of sport because of their immersion in it. But they also need to commit to broader political factions working with and on behalf of the public, with and through sport.

\section{POSTSCRIPT: A WORLD CUP SUCCESS THAT DID NOT GO COMPLETELY TO PLAN}

Brazil 2014 FIFA World Cup has now come and gone. The tournament was watched by a record number of viewers, Germany defeated Argentina in the final after humiliating Luiz Felipe Scolari's side 7-1 in a semi- final that did not go according to plan for the host nation. Such a defeat is unlikely to be forgotten nor is the level of domestic unrest or the issues that the protesters were fighting for likely to be diluted in the run up to the 2016 Rio de Janeiro Olympic Games. Given the extent to which soft power has infiltrated the rhetoric of states hosting international sporting events, the spotlight on Brazil, Russia and Qatar is likely to remain for some time.

Commenting on whether Brazil 2014 was a success the UK Shadow Minister for International Development suggested that:

It is perhaps too early to say if the World Cup will leave a lasting legacy for Brazil's people but the performance of it's football team would not have left a feel-good factor and could yet still lead people to ask about the direction of Brazil's politics and certainly the direction of its national sport. ${ }^{4}$

If the plan was to reproduce the Brazilian stereotype of carnival, passion, and samba style football as a basis of a sixth world cup success then Brazil 2014 has left more questions than answers. If the plan was to host a cost effective FIFA World Cup (this has been the most expensive World Cup so far) that bought happiness for Brazilians and others then it has only been a partial success. Widespread demonstrations highlighted a range of problems in Brazil, including governance, inefficiency, inequality and whether the high level of public spending on this major sporting event was worth it.

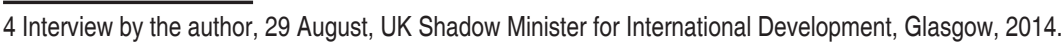


It is worth recalling the words of two Brazilian Presidents. President Lula da Silva in 2009, after hearing that Rio de Janeiro would stage the Olympics, stated that "Today is the day that Brazil gained it's international citizenship... Brazil has left behind the level of second-class countries and entered the rank of first class countries" (BELLOS, 2014, p. 5). In 2011 President Rouseff added that the way forward for Brazil is not only in economic growth but also investment in Brazil's cultural presence in the world (CASTRO, 2013). If the plan was to host the World Cup and the Olympics as a catalyst for further establishing prestige and image as a part of a soft power strategy of challenging an established world order then it has partially succeeded. In an age where world orders are unfolding then the 2014 World Cup was a useful diplomatic tool to Brazil.

If the plan was to remind the world of Brazil's tradition of linking football to political activism then Brazil 2014 could also be seen as a success. Such a tradition was encapsulated best in the late Brazilian World Cup captain (1982 and 1986) and political activist Socrates (19542011) who fought for democracy from inside the football world but also joined struggles for civil liberties in Brazil during the 1980s. Socrates grasped the platform that football gave him and refused to divorce football from the fight for social change (KNIJNIK, 2014).

Under the leadership of Socrates, Corinthians came to adopt a democratic system. Both the players and the staff had an equal vote to make decisions that would affect the team on the field. During this period, Brazil was under a military dictatorship; democracy did not figure and Corinthians helped to provide an example of how a democratic system could function. The team shocked the nation by entering the pitch with political messages on their shirts. The late Socrates, a man whose personal heroes included political activists and "intellectuals" such as John Lennon, Fidel Castro and Che Guevara, became embraced in the hearts of many Brazilians. If the events surrounding the 2014 FIFA World Cup were a continuation of this link between football and political activism then it could be argued that it was a partial success.

Finally if football was not a World Cup success for the Brazilian class of 2014 then anyone who had the opportunity to watch the endless football skill being practiced on the beaches of Rio at the same time should be left in no doubt that football in Brazil remains popular and could rise again. It is a point I put to the former Liverpool Captain Alan Hansen, who had been covering the 2014 World Cup for television:

\begin{abstract}
GJ: Was Brazil 2014 a success?
AH: It was a massive success, the viewing figures for both BBC [British Broadcasting Corporation] and ITV [Independent Television] were the highest ever and the event elevated the World Cup back to where it should always be... we were treated to an extravaganza and while Brazil might not have delivered on the pitch for Brazilian supporters, the tournament delivered. The problem for Brazil was that they did not have a centre forward which was amazing because if you go down to the Copacabana Beach the young football talent and skill that is on display is just out of this world ${ }^{5}$
\end{abstract}

\title{
6 CONCLUDING REMARKS
}

Those working in sport need not necessarily be confined to the side-lines; they can be active social and political resources. Sport can be a resource of hope, opening doors for people, places and communities, fighting for just causes. Sport can help to make the art of the possible,

5 Interview by the author, 3 September, former Captain of Liverpool Football Club and football analyst covering the FIFA 2014 World Cup in Brazil, East Lothian, 2014. 
possible. Those working in sport both within and outside of the university are stronger working together than apart, but they need to acknowledge a commitment and alignment in order to be effective agents of change.

If we acknowledge the first, that sport can help with the art of the possible, and act on the second, political commitment and alignment, then we might just be able to start to address the promise and possibilities of sport as a resource of hope in different parts of the world - just as the young lecturer from the Federal University of Rio de Janeiro used the platforms and skills afforded to him as a public intellectual working through sport. Just as Socrates did as he fought for Brazilian democracy through football for much of his political and footballing life, because for him and others they could not be separated.

Universities are really important here - they have stood the test of time. More importantly, the idea of the university itself is about discovery, problem solving, freedom, public engagement, commitment to communities, making the art of the possible, possible. All intellectuals whether they be public, traditional, vernacular or organic should take their place in the vanguard of a movement for the bettering of humanity.

\section{REFERENCES}

ADONIS, Andrew. Education, education, education: Reforming England's schools. London: Biteback, 2012.

BAIRNER, Alan. Sport, intellectuals and public sociology: Obstacles and opportunities. International Review for the Sociology of Sport, London, v. 44, n. 2-3, p. 115-130, 2009.

BELLOS, Alex. Brazil's Politicians banking on world cup victory to help soothe unrest. The Guardian, London, p. 1, June $8^{\text {th }}, 2014$.

BOND, Patrick. Zuma's own goal. The Times, London, p. 17, October 22 ${ }^{\text {nd }}, 2009$.

BOYKOFF, Jules. The anti-Olympics. New Left Review, London, v. 67, p. 41-61, Jan./Feb. 2011.

BURAWOY, Michael. Our livelihood is at stake: We must pursue relationships beyond the university. Network, London, n. 111, p. 27-30, summer 2012.

BURT, Jason. England hope rests on whole new ball game. The Sunday Telegraph, London, p. 6-8, December $8^{\text {th }}, 2013$, p. 6-8.

CALVERT, Jonathan; BLAKE, Heidi. Huge email cache reveals secrets of Qatar's shock victory. The Sunday Times, London, p. 1, June 1 ${ }^{\text {st }}, 2014$.

CASTRO, Andreia. 2014 FIFA world cup and 2016 Olympic games: Brazil's strategy to win hearts and minds through sports and football. Public Diplomacy Magazine, Los Angeles, p. 28-35, winter, 2013.

COLLINI, Stefan. What are universities for? London: Penguin, 2012.

COOPER, Andrew. Celebrity diplomacy. London: Paradigm, 2008.

DOCHERTY, Thomas. For the university: Democracy and the future of the institution. New York: Bloomsbury, 2011.

FARRED, Grant. What is my name? Black vernacular intellectuals. Minneapolis. University of Minnesota Press, 2003.

GILROY, Paul. Britain's intellectuals: Leading thinkers have their say. The Guardian, London, May $8^{\text {th }}$, 2011. Available at: http://www.theguardian.com/culture/2011/may/08/public-intellectuals-britain 
GONZALEZ, Cristina. Clark Kerr's University of California: Leadership, diversity and planning in higher education. New Brunswick, NJ: Transaction, 2011.

GOURLEY, Brenda. In defence of the intellectual: Robbins lecture. Stirling: University of Stirling, 2002. HIND, Dan. The return of the public. London: Bloomsbury, 2012.

JARVIE, Grant. Universities as resources of hope and progress in a changing and challenging world. Keynote speech delivered at the Leisure Studies Association Annual Conference, Edinburgh, 2013.

JARVIE, Grant. How can I pay my bills? the real sadness behind the administration of Glasgow Rangers Football Club. Glasgow: Jimmy Reid Foundation, February $15^{\text {th }}$, 2012. Available at: $<$ http:// reidfoundation.org/2012/02/how-can-i-pay-my-bills-the-real-sadness-behind-the-administration-ofglasgow-rangers-football-club/\#respond->. Accessed: $5^{\text {th }}$ January 2014.

JARVIE, Grant. Sport, social change and the public intellectual. International Review for the Sociology of Sport, London, v. 42, n. 4, p. 411-425, 2007.

JARVIE, Grant; THORNTON, James. Sport, culture and society. London: Routledge, 2012.

JENNINGS, Andrew. Foul! The secret world of FIFA: Bribes, vote rigging and ticket scandals. London: Harpersport, 2006.

KNIJNIK, Jorge. Playing for Freedom: Socrates, Futebol-Arte and Democratic Struggle in Brazil. Soccer and Society, London, v. 15, n. 2, p. 634-654, 2014.

KERR, lan. John Henry Newman: A biography. Oxford: Oxford University Press, 2009.

KERR, Clark. The uses of the university. Cambridge: Harvard University Press, 2001.

MELO, Demian. They won the battle for the buses but the struggle for Brazil's future goes on. The Conversation, Boston, p. 1-3, June 20 2013.

NAYLOR, David. Canada's universities slip in rankings. The Globe and Mail, Montreal, p. A4, October $4^{\text {th }} 2012$.

ORGANISATION FOR ECONOMIC CO-OPERATION AND DEVELOPMENT - OECD. OECD Economic Surveys Canada. June 2012 Overview. Available at: <www.oecd.org/eco/50543310.pdf>. Accessed on: January 1 1t, 2014.

REID, Jimmy. Alienation. Rectorial Address to the University of Glasgow. 1972. Available at: www.educationscotland.gov.uk/images/ugd057-1_jimmy reid rector_address booklet_1972_opt tci. Accessed on April 21 2014.

RODRIGUES, Thiago; BRANCOLI, Fernando. Brazil world cup protests stir painful memory of oppression. The Conversation, Boston, May 21 2014.

SAID, Edward. The case of the intellectual. The Age, May, p. 5-12, 2001.

SEN, Amartya. The idea of justice. London: Allen and Unwin, 2009.

SEN, Amartya. Identity and violence: The illusion of destiny. London: Allen and Unwin, 2006.

SEN, Amartya. Symposium on Amartya Sen's Philosophy: $4^{\text {th }}$ Reply. Economics and Philosophy, London, v. 17, n. 1, p. 51-66, 2001.

SEN, Amartya. Development as freedom. Oxford: Oxford University Press, 2000.

SINGER, Andre. Rebellion in Brazil. New Left Review, London, v. 85, p. 19-37, Jan./Feb. 2014.

SKULASON, Pall. The Role of Universities: Speech delivered at the quality assurance agency/ scotland enhancement themes $8^{\text {th }}$ Annual Conference. Edinburgh: Heriot-Watt University, 2010. 
SONTAG, Susan. Where the stress falls. London: Jonathan Cape, 2002.

SUTHERLAND, Stewart. What are our universities for? Speech delivered at the Royal Society of Edinburgh. Edinburgh, 2011.

UNESCO. Reaching the marginalised: Education for all. Paris: UNESCO, 2010.

UNIVERSITIES SCOTLAND. Delivering for Scotland: University outcome agreements 2013-14. Edinburgh: Universities Scotland, 2014

WILLIAMS, Raymond. Resources of hope. London: Verso, 1989. 


\section{Corresponding author:}

Moray House School of Education

The University of Edinburgh

Edinburgh, Eh8 8AQ - Scotland, United Kingdom

\section{Acknowledgement:}

I am grateful for the suggestions made by a number of reviewers who read earlier drafts of this paper. I am also grateful to the hospitality, study space and co-operation provided by the University of Toronto that helped to sharpen my thinking about the content. 